\title{
Develop IEC Material By PLHA to lead a positive life
}

\author{
Santosh Chettri
}

From $16^{\text {th }}$ International Symposium on HIV and Emerging Infectious Diseases

Marseille, France. 24-26 March 2010

\section{Background}

There is a scarcity of IEC materials necessary in disseminating information about HIV/AIDS to the most at risk and hard to reach populations, in particular information regarding stigma and discrimination faced by PLWHA. Furthermore, involvement of PLWHA in designing such IEC is virtually non existent.

\section{Methods}

Family Health International (FHI) and Oxygen Research and Development Forum (ORDF) conceptualized a process of Care and Support IEC material development involving local PLWHA consultants. Two groups of four consultants each worked for six months and adapted booklets 1 through 5 developed in Cambodia by FHI/ USAID to the Nepali context. The booklets provide information along with sketches about HIV/AIDS, nutritional needs of PLWHA, stigma and discrimination, social and family support, taking care of one's body and health, income generation, OIs and ARVs etc. The users of the booklet are individual outreach educators who work with illiterate vulnerable communities across Nepal.

\section{Results}

IEC materials development is a technical process that needs a lot of careful planning and orientation. Those involved in the process should have real knowledge of the issues that are of utmost importance to the targeted users. Care and attention needs to be given to language, social norms, and depiction. Involvement of local PLWHA is of utmost importance when developing IEC and other materials. In addition to creating booklets that are representative of the local needs and situation,

Correspondence: santosh.chettri@gmail.com

National Association of People living with HIV/AIDS in Nepal (NAP+N), Kathmandu, Nepal exposure to working in an office environment as consultants making steady income and gaining much needed skills in computer, translation, editing and sketching helps develop capacities of the involved consultants significantly.

\section{Discussion}

For ensuring the design of effective IEC materials related to HIV/AIDS, it is imperative that local PLWHA be involved in the planning, design, pretest and launch phases. Involvement of community PLWHA will also contribute towards capacity development and skills enhancement.

Published: 11 May 2010

doi:10.1186/1742-4690-7-S1-P149

Cite this article as: Chettri: Develop IEC Material By PLHA to lead a positive life. Retrovirology 2010 7(Suppl 1):P149.

Submit your next manuscript to BioMed Central and take full advantage of:

- Convenient online submission

- Thorough peer review

- No space constraints or color figure charges

- Immediate publication on acceptance

- Inclusion in PubMed, CAS, Scopus and Google Scholar

- Research which is freely available for redistribution

Submit your manuscript at www.biomedcentral.com/submit 